\title{
The impact of a bio-fertilizer on the soil organic matter status and carbon sequestration-results from a field-scale study
}

\author{
Bożena Dębska ${ }^{1}$. Jacek Długosz ${ }^{2}$ - Anna Piotrowska-Długosz ${ }^{2}$. \\ Magdalena Banach-Szott ${ }^{1}$
}

Received: 19 October 2015 / Accepted: 5 April 2016/Published online: 23 April 2016

(C) The Author(s) 2016. This article is published with open access at Springerlink.com

\begin{abstract}
Purpose The application of bio-fertilizers is one of the management practices that can help to maintain or increase the content of organic matter $(\mathrm{OM})$ and improve soil fertility in arable soils. While some results have been obtained in relation to the influence of bio-fertilizers on organic matter content, less in known about the fractional composition of humus.

Materials and methods The aim of this study was to determine the effects of the bio-fertilizer UGmax on soil total organic carbon (TOC), dissolved organic carbon (DOC), and the fractional composition of organic matter (C of humic acids (CHAs), $\mathrm{C}$ of fulvic acids (CFAs), and $\mathrm{C}$ in humins) in the humus horizon of an arable field. Measurements were taken in 2005 before the application of UGmax and in 2008, 3 years after its application, which was done in 2005, 2006, and 2007. Forty soil samples were taken in 2005 (the control year without UGmax), while 20 samples were taken after UGmax treatment and 20 from the control in 2008. Samples were always collected after the plants were harvested.

Results and discussion After the 3-year period of the experiment, the TOC content was $6.3 \%$ higher in plots on which UGmax was applied in comparison to the control, while the DOC content was 0.19 percentage points lower after 3 years
\end{abstract}

Responsible editor: Zucong Cai

Anna Piotrowska-Długosz ap03@wp.pl

1 Department of Environmental Chemistry, Faculty of Agriculture and Biotechnology, UTP University of Science and Technology, 6 Bernardyńska St., 85-029 Bydgoszcz, Poland

2 Department of Soil Science and Soil Protection, Faculty of Agriculture and Biotechnology, UTP University of Science and Technology, 6 Bernardyńska St., 85-029 Bydgoszcz, Poland of bio-fertilizer use as compared to the initial year of the experiment. The contribution of DOC to TOC decreased significantly after the application of UGmax in comparison with the control. The content of CFAs and its contribution in the TOC pools in soil without UGmax was higher at the end of the experiment compared to the beginning, while there was an inverse relationship in the soil with the bio-fertilizer. In comparison with the control, organic matter in the soil treated with UGmax had a higher content of $\mathrm{C}$ of humic acids, $\mathrm{C}$ in humins, and higher CHAs/CFAs ratio.

Conclusions We conclude that the use of a bio-fertilizer that increases the stable fractions of organic matter provides evidence of an increase in the soil OM stability. In turn, the contribution of the organic matter fractions that are more resistant to decomposition is crucial for increasing soil carbon sequestration.

Keywords Bio-fertilizer · Coffulvic acids $\cdot$ C of humic acids $\mathrm{C}$ in humins $\cdot$ Total and dissolved organic $\mathrm{C}$

\section{Introduction}

Long-term soil and crop management such as the excessive use of inorganic fertilizers and pesticides along with reduced organic manure amendments to the soil, simplified crop rotations and monocultures, the use of heavy machinery, and inadequate practices of soil management exert a considerable influence on soil quality by worsening the physicochemical and biological properties of the soil (Melero et al. 2006; Liu et al. 2010). Consequently, changes in soil management may lead to a decrease of organic matter content followed by a diminution in the sustainability of the soil, which can be expected over the long term (Valarini et al. 2003). Increasing concern about the long-term productivity and sustainability 
of soil quality has emphasized the need to the develop management practices that reduce the potentially negative impact of agricultural activities in which proper OM management appears to be the most important factor (Chander et al. 1997).

The content of organic matter is an essential indicator of soil quality and fertility (Haynes 2005). Organic matter is one of three soil components that are crucial for its physicochemical properties, such as its sorptive and buffer abilities as well as its biodiversity and biological activity. Because of the positive influence of organic matter on soil functionality, it is imperative that its resources be maintained or improved (Lal 2011; Krasowicz et al. 2011).

Specific OM fractions differ in mobility. The dissolved organic matter (DOM) is the most mobile fraction of organic matter. DOM is the product of the transformation and decomposition of carbon compounds that are built into soil organic material. DOM consists of simple organic compounds that have a nonspecific humic substance character (fatty acids, organic acids, amino acids, carbohydrates) and water-soluble compounds that have a humus character. The formation and translocation of DOM in soils is a very important process of organic matter transformation because the DOM takes part in the $\mathrm{C}$ cycling between ecosystems even though it only accounts for about $1 \%$ of the total organic carbon in agricultural soils (Gonet and Dębska 2006; Li et al. 2014). It should be kept in mind that the content, production, and consumption of dissolved organic matter are closely related to soil microbial activity. Microbial activity not only contributes to an increase of dissolved organic substances but also affects the chemical composition of DOM, which leads to changes in its bioavailability and interaction with other dissolved substances. The susceptibility of DOM to microbiological decomposition and its rate of decomposition depend on its chemical structure and dissolved organic carbon compounds may be both the substrates as well as the products in the processes of the microbiological transformation of organic matter that lead to the formation of complex compounds (Marschner and Kalbitz 2003; Kalbitz et al. 2003; Kiikkilä et al. 2014). The humified organic matter in soil, which is operationally separated into humic acids (CHAs), fulvic acids (CFAs), and humin (C humins), is considered to be the most microbially stable reservoir of soil organic matter. Humins are the most passive fraction of humified matter. The carbon ratio of CHAs to CFAs (CHAs/ CFAs) has been used as a turnover indicator to describe the intensity of the humification process of soil OM (Yang et al. 2004). However, one should note that the properties of the organic matter of soils can be modified by, e.g., the cultivation method of the land (crop rotation, fertilization) as well as by other external factors (Orlov 1986; Gonet and Dębska 1999, 2006; Dębska 2004; Dębska et al. 2012).

The successive reduction of soil OM as a consequence of the limited application of biomass to the soil as well as gas emissions and elution (such as soil dissolved carbon) has resulted in activities that are focused on increasing soil carbon fixation-its sequestration (Smith 2004). The process of carbon sequestration is defined as the fixation of carbon by plants, followed by their decomposition and humification in soil. This concept, which was proposed mainly in connection with a decrease in the emissions of greenhouse gases into the atmosphere, is now used to describe soil processes that limit soil carbon loss (Lal 2011). In recent years, interest in the prevention of soil organic matter loss has been growing rapidly and a great deal of attention has been paid to this problem in the context of the Soil Thematic Strategy of European Union, which was presented in COM Directive 232 (2006).

The application of bio-fertilizers that contain living microorganisms is one of the management practices that can help to maintain or increase the content of organic matter and improve soil fertility in arable soils. Although bio-fertilizers have been known for many years, relatively little research has been done to document their effects (or noneffects) on crop production or to provide evidence of their potential effects on soil properties and processes, especially in outstanding peer reviewed scientific journals (Dinesh et al. 2010; Khaliq et al. 2006; Mayer et al. 2010; Piotrowska et al. 2012; Wu et al. 2005; Zhao et al. 2005). Previous research has indicated positive, rarely negative, and the lack of any significant influence of bio-fertilizers on soil physicochemical and biological properties (Kaczmarek et al. 2008; Mayer et al. 2010; Tejada et al. 2011; Piotrowska et al. 2012). While some, usually contradictory, results have been obtained in relation to the influence of bio-fertilizers on the organic matter content (e.g., Valarini et al. 2003; Nisha et al. 2007; Schenck zu SchweinsbergMickan and Müller 2009; Pardo et al. 2010; Jakubus et al. 2013), less is known about the fractional composition of humus (Valarini et al. 2003), which impedes any further research in this field. Some researchers have noted the influence of biofertilizers on the acceleration of the humification of fresh organic matter that is introduced into the soil (Valarini et al. 2003; Fatunbi and Ncube 2009; Piotrowska et al. 2012). That is why, especially when a large amount of exogenous organic matter (e.g., natural fertilizers or different bio-wastes) is introduced into the soil, the application of specially composed bio-fertilizers is very important in order to accelerate the transformation of the biomass.

An increasing number of different microbial preparations for agricultural use are available on the market and an increasing interest in their use in agricultural practice, as well as a few ambiguous results of research, have led to further investigations into the relationships between the soil environment and microbial fertilizers. Consequently, the aim of the present paper was to determine the effect of the bio-fertilizer UGmax on the fractional composition of soil organic matter and to determine the role of bio-fertilizers in soil carbon 
sequestration and simultaneously in increasing its resources, which is part of the strategy to counteract climate changes.

\section{Material and methods}

\subsection{Study site and soil sampling description}

The study was carried out on an arable field of winter wheat $(2005,2006,2008)$ and winter rape (2007) that is situated in the southern part of the Sepopolska Plain (54 $11^{\circ} 54^{\prime \prime} \mathrm{N}, 20^{\circ}$ $38^{\prime} 12^{\prime \prime} \mathrm{E}$ ) in northern Poland. According to the WRB (IUSS Working Group, WRB 2007), the soil used was a eutric, gleyic Cambisol that was composed of $45 \%$ sandy clay loam, $35 \%$ fine sandy loam, $10 \%$ loam, $5 \%$ clay loam, and $5 \%$ clay. A research area of 2 ha was set up for the experiment in 2005, and 40 sampling points were marked using GPS (20 samples from the control area - control 2005 and 20 from the area on which the UGmax was to be applied-UGmax 2005). The second sampling was done in 2008 (20 samples from the control and 20 from the field treated with the UGmax). Soil samples were collected from the soil humus horizon after the crop was harvested and prior to the application of UGmax. The time and the doses of the application of UGmax were followed according to the producer's recommendation. One half of the area that was studied was supplemented with UGmax bio-fertilizer on the stubble after harvest $(0.71$ per hectare) and as top-dressing in spring ( 0.31 per hectare), while the other half was the control. The control treatment with sterilized UGmax, which is usually recommended, was not performed because in the preliminary study (the pot experiment), there were no significant differences between objects with sterilized UGmax and the control without the bio-fertilizer. This was probably due to the lack of additives (such as molasses), a low content of elements in the bio-fertilizer and the small amount of UGmax that was applied within the year ( 111 per hectare). The chemical and microbiological composition of UGmax is given in Table 1. The crop rotation, the type, and the rates of the application of the nitrogen fertilizer that was applied during the experiment are shown in Table 2. No phosphorus or potassium fertilization was applied during the experiment. Rainfall and air temperature data were recorded at a weather station located $3 \mathrm{~km}$ west of the site of the experiment. The average annual temperature and rainfall in 2005 was about $7.6^{\circ} \mathrm{C}$ and $492 \mathrm{~mm}$, while in 2008 , about $8.7{ }^{\circ} \mathrm{C}$ and $676 \mathrm{~mm}$, respectively. The detailed data of weather condition during the experiment as well as the basic properties of the soil under study (e.g., pH, total N, clay, silt, and sand fractions) was presented earlier (Piotrowska et al. 2012).
Table 1 Chemical and microbiological composition of the UGmax biofertilizer

\begin{tabular}{ll}
\hline Elements (total values) & $\left(\mu \mathrm{g} \mathrm{ml}^{-1}\right)$ \\
$\mathrm{N}$ & 1800 \\
$\mathrm{P}$ & 250 \\
$\mathrm{~K}$ & 3000 \\
$\mathrm{Mg}$ & 120 \\
$\mathrm{~S}$ & 350 \\
$\mathrm{Na}$ & 350 \\
$\mathrm{Mn}$ & 7 \\
$\mathrm{Bacteria}$ & $\left.(\mathrm{CFU} \mathrm{m})^{-1}\right)$ \\
Lactic acid bacteria & $7.5 \times 10^{2}$ \\
Pseudomons spp. & $1.6 \times 10^{5}$ \\
Penicillium & $1.8 \times 10^{4}$ \\
Actinomycetes spp. & $3 \times 10^{3}$ \\
\hline
\end{tabular}

\subsection{Determination of the TOC content and the composition of the soil organic matter quality}

The content of total organic carbon (TOC) was determined using a Vario Max CNS analyzer (Elementar, Germany). The sensitivity of the apparatus was $0.001 \mathrm{~g} \mathrm{~kg}^{-1}$. All analyses and measurements were done at least in triplicate, as long as the error among three replications was less than $2 \%$.

Dissolved organic carbon (DOC) concentrations were measured in solutions that were obtained after extraction with $0.004 \mathrm{M} \mathrm{CaCl}_{2}$. The extraction was done using the soil sample to extractant ratio of 1:10 over $1 \mathrm{~h}$. DOC content was assayed using a TOCN Multi N/C 3100 Analityk Jena (Germany) (Gonet et al. 2002). The sensitivity of the apparatus was $0.01 \mathrm{~g} \mathrm{~L}^{-1}$. DOC was measured until the measurement error was less than $2 \%$, and no fewer than three replications were done.

The content of DOC was expressed in $\mathrm{mg} \mathrm{kg}^{-1}$ of the dry matter of a soil sample and as a percentage share in the TOC pool. TOC stock $\left(\mathrm{kg} \mathrm{m}^{-2}\right)$ was calculated according to the following formula proposed by Kucuker et al. (2015):

TOC stock $=(\mathrm{C} \times \mathrm{pb} \times \mathrm{Z}) / 100$

where

C Carbon content (\%)

Z Thickness $-0.25 \mathrm{~m}$

$\mathrm{pb}$ Bulk density $\left(\mathrm{kg} \mathrm{m}^{-3}\right)$

The fractional composition of humus was assayed based on the carbon fractions that were determined in the extracts using a Multi N/C 3100 Analityk Jena (Germany), according to following procedure:

- Decalcification $(24 \mathrm{~h})$ with $0.05 \mathrm{M} \mathrm{HCl}(1: 10 w / v)$, Cdeca-carbon in solutions after decalcification

- Extraction $(24 \mathrm{~h})$ of the remaining solid with $0.5 \mathrm{M}$ $\mathrm{NaOH}(1: 10 w / v)$ with occasional mixing, followed by 
Table 2 Crop rotation and fertilization used in the study

\begin{tabular}{|c|c|c|c|c|c|}
\hline \multirow[t]{2}{*}{ Year } & \multirow[t]{2}{*}{ Forecrop } & \multicolumn{2}{|l|}{$\mathrm{N}$ fertilization } & \multicolumn{2}{|c|}{ Yield $\left(\mathrm{Mg} \mathrm{ha}^{-1}\right)$} \\
\hline & & Fertilizer & Dose $\left(\mathrm{kg} \mathrm{ha}^{-1}\right)$ & Control & UGmax \\
\hline 2005 & Winter wheat & Urea & 150 & 5.9 & 6.1 \\
\hline 2006 & Winter wheat & Urea & 150 & 5.0 & 5.4 \\
\hline \multirow[t]{3}{*}{2007} & Winter rape & Urea & 50 & 3.0 & 3.4 \\
\hline & & Ammonium nitrate & 200 & & \\
\hline & & Ammonium sulfate & 200 & & \\
\hline 2008 & Winter wheat & Urea & 200 & 6.1 & 7.3 \\
\hline
\end{tabular}

centrifugation; $\mathrm{C}(\mathrm{HAs}+\mathrm{FAs})$ - sum of the carbon of humic and fulvic acids

- Precipitation (24 h) of humic acids from the resulting alkaline extract with $2 \mathrm{M} \mathrm{HCl}$ to $\mathrm{pH}=2$ and centrifugation; CFAs - carbon of fulvic acids in solutions

The carbon in humic acids (CHAs) and carbon in humins (C humins) were calculated from the difference:

$\mathrm{CHAs}=\mathrm{C}(\mathrm{HAs}+\mathrm{FAs})-\mathrm{CFA}_{\mathrm{S}}$ $\mathrm{C}$ humins $=\mathrm{TOC}-\mathrm{CHAs}-\mathrm{CFAs}-\mathrm{Cdeca}$

The fractional composition was expressed in $\mathrm{mg} \mathrm{kg}^{-1}$ of dry matter of a soil sample and as the \% share of the respective fractions in the TOC pool.

\subsection{Statistical calculations}

The dataset was analyzed in the field in a classical way in order to investigate the general status of the soil $\mathrm{C}$ fractions with UGmax and without the bio-fertilizer (control) in 2005 and 2008. The statistical parameters such as mean, maximum and minimum, standard deviation (SD), and coefficient of variation (CV\%) were evaluated using STATISTICA v. 9.0 software. The dataset was checked for normality using the Shapiro-Wilk test $(\alpha=5 \%)$. Since normality was the general observation, we chose not to transform the values before further analyses. A one-way analysis of variance (ANOVA) was performed to examine the effect of the application of UGmax (UGmax and control) on the properties that were studied within the same year. In the case of significant $F$ tests, differences between the group means were assessed using the Tukey test $(p \leq 0.05)$.

The coefficient of variation (CV) gives a normalized measure of spreading about the mean. Wilding (1985) proposed a classification scheme for identifying the extent of variability for soil properties based on their $\mathrm{CV}$ values in which values of $0-15,16-35$, and $>36 \%$ indicate little, moderate, or high variability, respectively.

\section{Results and discussion}

\subsection{The content of TOC in soil}

One of the essential property that are used to determine organic matter content in soils is the content of carbon in organic compounds, i.e., TOC. Prior to the application of UGmax (2005), there was no significant difference in the TOC content between the area that was selected for the application of UGmax $\left(14.0 \mathrm{~g} \mathrm{~kg}^{-1}\right)$ and the control $\left(14.8 \mathrm{~g} \mathrm{~kg}^{-1}\right)$, while in 2008, the application of UGmax had significantly increased the TOC concentration as compared to the control (Fig. 1a). At the end of the experiment, the mean value of TOC content amounted to $15.8 \mathrm{~g} \mathrm{~kg}^{-1}$. There were no significant changes in the carbon stock in the control soil between 2005 and 2008, while the application of UGmax over a 3-year period significantly increased the TOC stock (Fig. 1b). In the literature, the data that relate to the organic $\mathrm{C}$ content in soil that is under the influence of bio-fertilizers are contradictory. In the study of Valarini et al. (2003), the percentage of organic C increased significantly after 3 months in soil that had been treated with various green crop residues and with animal manure with the addition of $30 \mathrm{~L} \mathrm{ha}^{-1}$ of effective microorganisms (EMs) as compared to the same objects without EM. According to the authors, this was probably due to the rapid decomposition of fresh or immature organic material and the manure that had been added to the soil and the intensive polymerization process (humification) of organic matter as influenced by the biofertilizer. The organic matter content in treatments with $\mathrm{N}$ fixer (Azotobacter chroococcum), $\mathrm{P}$ and $\mathrm{K}$ solublizers (Bacillus megaterium and Bacillus mucilaginous) with mycorrhizal fungi species, and an organic fertilizer (autoclaved chicken manure and the powder from a phosphate rock) increased by $75 \%$ in comparison to the uninoculated control (Wu et al. 2005). However, the results imply that the increase was not directly induced by the activity of soil microorganisms. Treatments with low fertilizer levels and a control exhibited a larger population of $\mathrm{N}$-fixing bacteria and higher mycorrhizal root colonization, but a relatively low OM content. Most soil microorganisms consume a considerable 

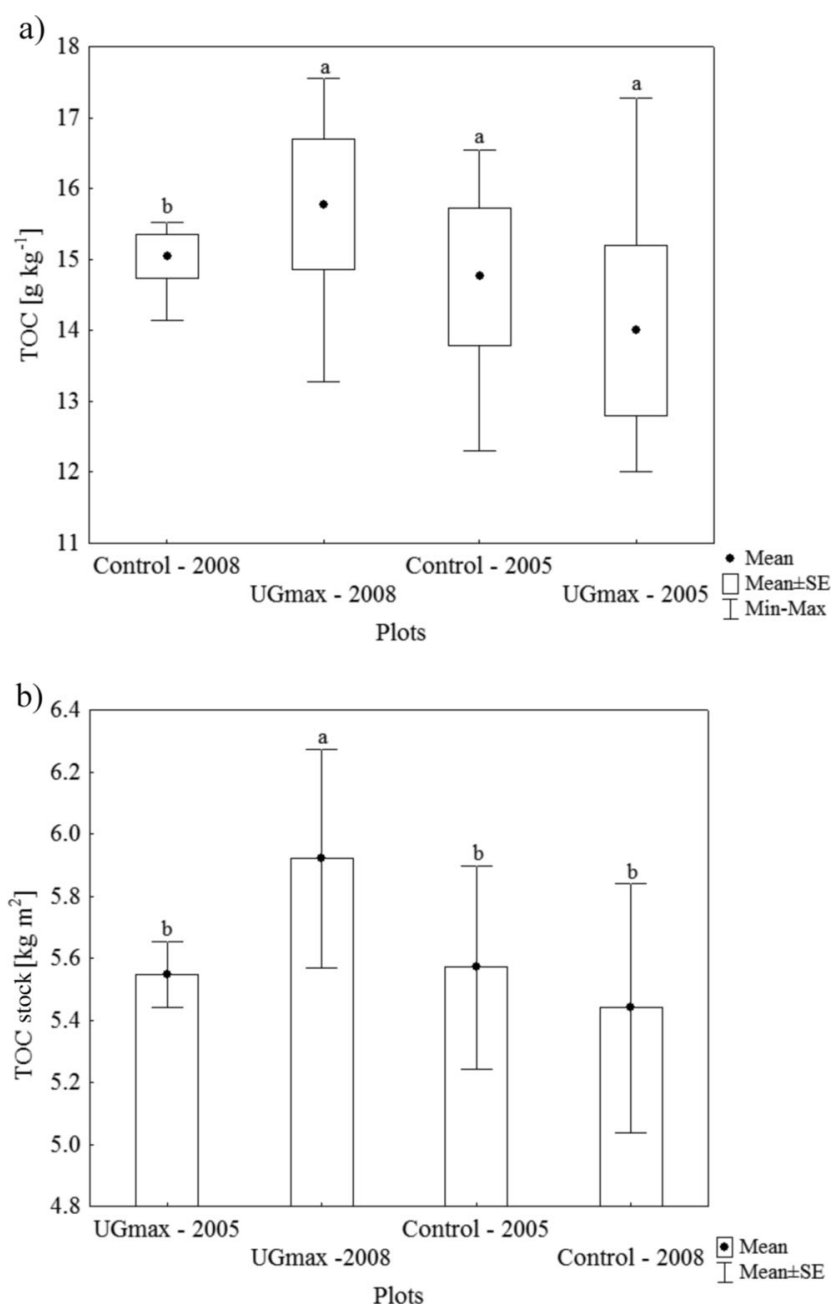

Fig. 1 Total organic carbon (TOC) content (a) and TOC stock (b); mean and standard error is given on each bar; values followed by the same lowercase letter in the same year are not significantly different at $p \leq 0.05$

amount of OM in order to generate the energy for maintenance and growth. Thus, some organic $\mathrm{C}$ is lost during the production of carbon dioxide. In a pot experiment, Nisha et al. (2007) observed that a bio-fertilizer consisting of three indigenous cyanobacterial isolates attained a significant increase in TOC content when applied to an organically poor ( $0.35 \%$ of organic $\mathrm{C}$ and $0.06 \%$ of nitrogen) semi-arid soil. As the authors stated, the higher TOC in this soil was attributed to the autotrophic nature of the cyanobacteria, which synthesize and add organic matter to the soil. Similarly, inoculation and further incubation with Nostoc $9 \mathrm{v}$ (cyanobacteria) promoted increases in organic carbon that ranged from $0.4 \mathrm{~g}$ $\mathrm{C} \mathrm{kg}^{-1}$ of soil to $9.0 \mathrm{~g} \mathrm{C} \mathrm{kg}^{-1}$ of soil (Pardo et al. 2010). In the study of Schenck zu Schweinsdberg-Mickan and Müller (2009), no or only marginal effects of EM on organic C were observed. According to the authors, the comparison with sterilized EM and molasses as the main additives in the EM suspension indicated that any effect of EM could be explained as a pure substrate effect without the influence of added living microorganisms. In this study, because of the lack of additives (such as molasses) and the low content of elements in the bio-fertilizer (Table 1), the effect of UGmax on soil carbon was due to the activity of microorganisms. The effect of UGmax on the increase of TOC may have an indirect cause, by affecting the yield of the plants. The consequence of the yield increase (Table 2) was an increase of the mass of post-harvest residues. It should be kept in mind that beyond the amount of the crop residues, their chemical composition is a significant determinant of their degradation process. The post-harvest residues of wheat and rape are characterized by high values of $\mathrm{C} / \mathrm{N}$ and $\mathrm{C} / \mathrm{P}$ ratios as well as a high content of lignin, which are not readily degradable (Gonet and Dębska 1999; Dębska et al. 2012).

\subsection{The content of DOC and its contribution to TOC}

The role of organic matter in soils is not only related to its content but also depends on its quality as well. The DOC is a very important fraction of organic matter, and its content is expressed based on the determination of carbon content in this fraction (Gonet et al. 2002; Gonet and Dębska 2006; Chen and Xu 2008; Guo et al. 2011; Li et al. 2014). It is believed that the formation of mobile compounds that consist of mineral components and dissolved organic matter is one of the reasons for carbon depletion in soil. The content of DOC in the control plot before starting the experiment ranged from 0.145 to $0.176 \mathrm{~g} \mathrm{~kg}^{-1}$ (mean $0.160 \mathrm{~g} \mathrm{~kg}^{-1}$ ) and from 0.125 to $0.175 \mathrm{~g} \mathrm{~kg}^{-1}$ (mean $0.150 \mathrm{~g} \mathrm{~kg}^{-1}$ ) after 3 years of the experiment (Fig. 2a). The application of the bio-fertilizer over a 3-year period caused a decrease in the DOC concentration. At the end of the experiment, the mean values of DOC were lower than the initial content in the soil with UGmax, which was similar to the control soil. Thus, the decrease in DOC was the result of both the application of UGmax and the other soil management practices. It should be kept in mind that the quality of organic matter depends mainly on the contribution of its particular fractions. As can be seen in Fig. 2b, the contribution of DOC to TOC decreased significantly after the application of UGmax in comparison with the control soil. The DOC content was 0.19 percentage points lower after 3 years of bio-fertilizer use as compared to 2005. Considering that DOM is the fraction of organic matter that is subjected to decomposition and washout, a decrease of the contribution of DOM in total organic matter after the application of UGmax could be considered to be a positive effect. The process that leads to the decrease of the DOM contribution in total organic matter could, simultaneously with an increase of total organic carbon, 

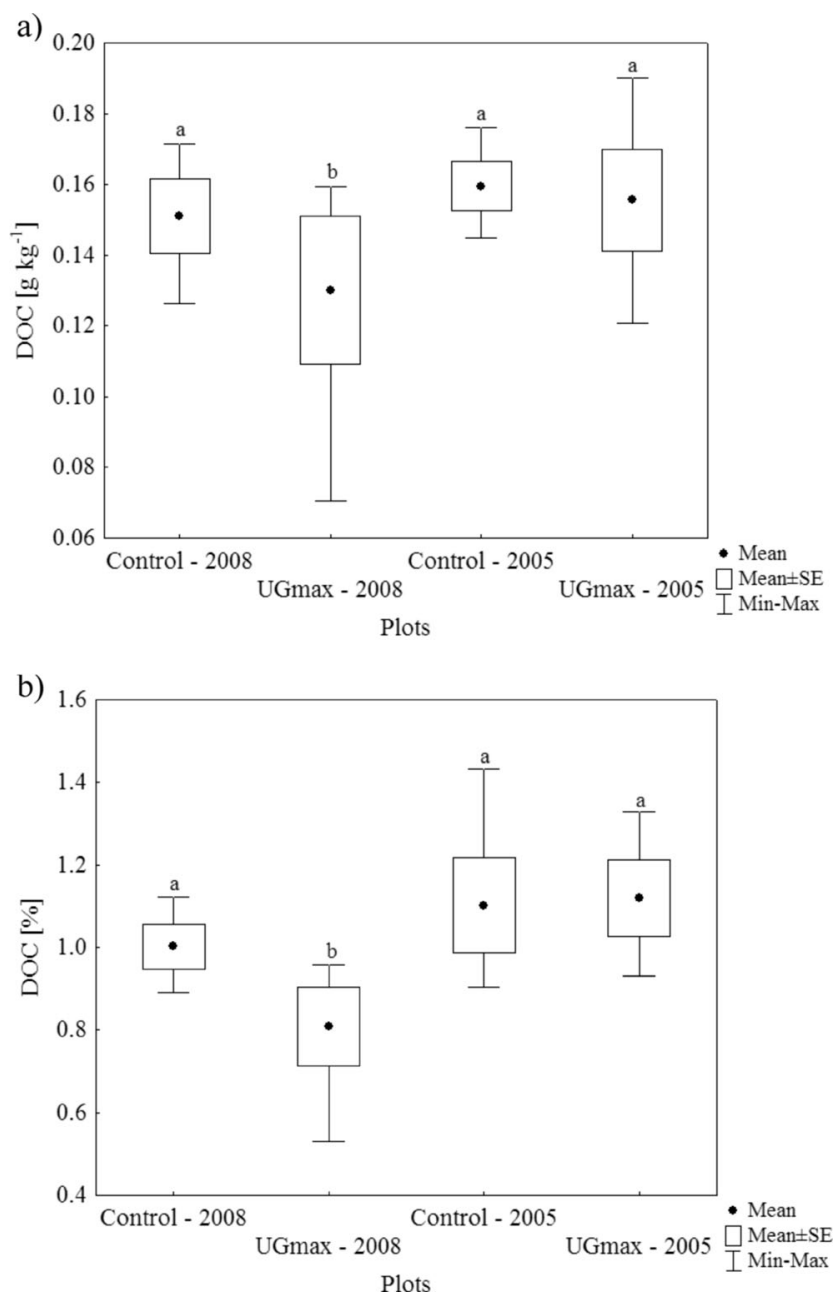

Fig. 2 Dissolved organic carbon (DOC) content (a) and its share in TOC content (b); mean and standard error is given on each bar; values followed by the same lowercase letter in the same year are not significantly different at $p \leq 0.05$

contribute to an increase in the role of sequestering the soil.

\subsection{Fractional composition of organic matter}

The properties of soil humus depend on, and simultaneously are characteristic for, different soil types. Humic acids, which are the main component of soil humus, specify the properties, and consequently, the role of humus in a natural environment. It is commonly known that the content of humic acids that are included in humus, as well as their properties is modified, e.g., by the kind of fertilization that is applied (Orlov 1986; Gonet 1989; Dębska 2004; Ventorino et al. 2011). In the process of organic matter fractionation, the content of carbon after decalcification (Cdeca), carbon of humic acids (CHAs) and fulvic acids (CFAs), and humins (C humins) were determined and calculated. The mean values of Cdeca ranged from 460.8 to $545.5 \mathrm{mg} \mathrm{kg}^{-1}$, and the data showed a slight differentiation according to their $\mathrm{CV}(\%)$ values (Table 3$)$. The content of this
Table 3 Content of various fractions of soil carbon $\left(\mathrm{mg} \mathrm{kg}^{-1}\right)$

\begin{tabular}{|c|c|c|c|c|c|}
\hline \multirow[b]{2}{*}{$\mathrm{C}$ fractions } & \multirow[b]{2}{*}{ Parameters } & \multicolumn{2}{|l|}{ Control } & \multicolumn{2}{|l|}{ UGmax } \\
\hline & & 2005 & 2008 & 2005 & 2008 \\
\hline \multirow[t]{5}{*}{ Cdeca } & Mean & 538.2 & 472.2 & 545.5 & 460.8 \\
\hline & Min & 509.5 & 419.7 & 534.4 & 393.7 \\
\hline & Max & 563.6 & 558.9 & 569.2 & 502.1 \\
\hline & SE & 14.3 & 30.4 & 8.0 & 24.5 \\
\hline & $\mathrm{CV}(\%)$ & 5.3 & 12.9 & 2.9 & 10.6 \\
\hline \multirow[t]{5}{*}{ CFAs } & Mean & 2835.6 & 3065.4 & 3062.2 & 2713.7 \\
\hline & Min & 2606.5 & 2828.8 & 2780.5 & 1990.3 \\
\hline & Max & 3256.5 & 3640.0 & 3619.5 & 3112.2 \\
\hline & SE & 192.4 & 192.2 & 255.3 & 189.1 \\
\hline & $\mathrm{CV}(\%)$ & 10.5 & 12.5 & 12.3 & 18.8 \\
\hline \multirow[t]{5}{*}{ CHAs } & Mean & 2237.2 & 2017.2 & 2450.3 & 2375.5 \\
\hline & Min & 1411.7 & 1583.7 & 1966.1 & 1667.1 \\
\hline & Max & 2737.5 & 2918.0 & 2975.7 & 3217.8 \\
\hline & SE & 316.4 & 306.5 & 206.6 & 390.4 \\
\hline & $\mathrm{CV}(\%)$ & 28.3 & 30.4 & 16.9 & 32.9 \\
\hline \multirow[t]{5}{*}{ C hhumins } & Mean & 9149.0 & 8445.2 & 8984.4 & 10227.5 \\
\hline & Min & 7772.3 & 7092.3 & 8200.9 & 8827.9 \\
\hline & Max & 9984.0 & 10163.1 & 9824.7 & 11475.8 \\
\hline & SE & 513.9 & 724.6 & 322.0 & 721.0 \\
\hline & $\mathrm{CV}(\%)$ & 11.2 & 17.2 & 7.7 & 14.1 \\
\hline
\end{tabular}

Cdeca carbon in solutions after decalcification, CFAs carbon of fulvic acids in solutions, CHAs carbon in humic acids, $C$ humins carbon in humins, $S E$ standard error, $C V$ coefficient of variation

fraction, both in the control and in the soil with UGmax, was lower at the end of the experiment as compared to the content at the beginning of the study. After 3 years of the application of UGmax, the contribution of Cdeca in the TOC pool was $2.93 \%$, while in 2005 , it was 0.7 percentage points higher and the difference in its participation was statistically significant (Table 4).

The content of CFAs and its contribution in the TOC pools in soil without UGmax was higher at the end of the experiment compared to the beginning, while the relationship was inverse in the soil with bio-fertilizer (Tables 3 and 4). The data related to the CFAs indicated a slight variability as was indicated by $\mathrm{CV}$ values between 7.6 and $13.1 \%$. After 3 years of the application of UGmax, the participation of CFAs in TOC was 4.9 percentage points lower as compared to control soil (2008) (Table 4). It should be emphasized that irrespective of the experiment plot, the content and the share of CFAs in the TOC pools was higher compared to the content and contribution of CHAs. After using UGmax over a 3-year period, the difference between the contributions of CFAs and CHAs to the TOC pool decreased (Table 4).

The content of the fraction of CHAs and its contribution to TOC in the soil with UGmax was higher as compared to the control soil (Tables 3 and 4). The significant influence of a bio-fertilizer (EMs) on CHAs was noted in the study of Valarini et al. (2003) in which treatments with fresh plant debris or animal manure with the addition of EM was 
Table 4 The contribution of humus fractions in TOC content (\%)

\begin{tabular}{|c|c|c|c|c|c|}
\hline \multirow[b]{2}{*}{$\mathrm{C}$ fractions } & \multirow[b]{2}{*}{ Parameters } & \multicolumn{2}{|c|}{ Control } & \multicolumn{2}{|c|}{ UGmax } \\
\hline & & 2005 & 2008 & 2005 & 2008 \\
\hline \multirow[t]{5}{*}{ Cdeca } & Mean & $3.68 \mathrm{a}$ & $3.39 \mathrm{a}$ & $3.63 \mathrm{a}$ & $2.93 \mathrm{~b}$ \\
\hline & Min & 3.40 & 3.23 & 3.50 & 2.74 \\
\hline & Max & 4.14 & 3.70 & 3.81 & 3.21 \\
\hline & SE & 0.16 & 0.11 & 0.07 & 0.10 \\
\hline & $\mathrm{CV}(\%)$ & 8.9 & 6.2 & 3.8 & 7.1 \\
\hline \multirow[t]{5}{*}{ CFAs } & Mean & $19.3 \mathrm{a}$ & $22.1 \mathrm{a}$ & $20.4 \mathrm{a}$ & $17.2 \mathrm{~b}$ \\
\hline & Min & 17.9 & 19.8 & 18.3 & 15.0 \\
\hline & Max & 21.2 & 24.1 & 23.3 & 19.9 \\
\hline & $\mathrm{SE}$ & 0.74 & 0.99 & 1.14 & 1.15 \\
\hline & $\mathrm{CV}(\%)$ & 7.6 & 9.0 & 11.2 & 13.1 \\
\hline \multirow[t]{5}{*}{ CHAs } & Mean & $14.9 \mathrm{~b}$ & $14.2 \mathrm{~b}$ & $16.3 \mathrm{a}$ & $15.0 \mathrm{a}$ \\
\hline & Min & 11.5 & 13.2 & 12.9 & 10.0 \\
\hline & Max & 17.0 & 16.9 & 19.5 & 20.6 \\
\hline & $\mathrm{SE}$ & 1.26 & 0.90 & 1.39 & 2.24 \\
\hline & $\mathrm{CV}(\%)$ & 16.9 & 12.7 & 17.0 & 29.8 \\
\hline \multirow[t]{5}{*}{ C humins } & Mean & $62.1 \mathrm{a}$ & $59.2 \mathrm{~b}$ & $59.7 \mathrm{~b}$ & $67.7 \mathrm{a}$ \\
\hline & Min & 60.4 & 58.8 & 57.5 & 56.4 \\
\hline & Max & 63.3 & 63.8 & 64.6 & 69.0 \\
\hline & SE & 0.69 & 1.66 & 1.65 & 2.96 \\
\hline & $\mathrm{CV}(\%)$ & 2.2 & 3.9 & 5.5 & 9.1 \\
\hline
\end{tabular}

Values followed by the same lowercase letter in the same year are not significantly different at $p<0.05$

Cdeca carbon in solutions after decalcification, CFAs carbon of fulvic acids in solutions, CHAs carbon in humic acids, $C$ humins carbon in humins, $S E$ standard error, $C V$ coefficient of variation

compared to the same plots but without a bio-fertilizer. In our study, irrespective of the experiment plot, a decrease in the content and the share of CHAs in TOC were noted during the experiment. After 3 years of the study, the mean difference in the share of CHAs in TOC between the control and UGmax soil amounted to 0.8 percentage points, while at the beginning of the experiment, it was 1.4 percentage points.

The humins fraction is the largest part of soil organic matter. In our study the participation of $\mathrm{C}$ humins in TOC ranged from 56.4 to $69.0 \%$ (Table 4). At the beginning of the experiment, the mean value and the share of $\mathrm{C}$ humins in TOC was higher in the control soil than in the field on which UGmax was to be applied, while an inverse relationship was noted at the end of the study (Tables 3 and 4). In light of the fact that the $\mathrm{C}$ humins is the fraction of organic matter that is the most resistant to decomposition, its statistically significant increase may indicate the significant role of UGmax bio-fertilizer in the processes of soil $\mathrm{C}$ sequestration.

According to Piotrowska et al. (2012), the incorporation of UGmax into the soil significantly increased the cellulase activity, which is the group of enzymes that take part in cellulose decomposition. On the one hand, the increase of enzymatic activity may indicate the processes of the mineralization of organic matter, while on the other hand, it may indicate the beginning of the humification process. As was stated by Orlov
(1986) and Ventorino et al. (2011), one of the mechanisms of humification is the polycondensation and polymerization of compounds that have a lower molecular mass that are formed from the biochemical transformation of macromolecules (cellulose, lignin). The data from this study, e.g., the higher contribution of the fraction of CHAs in TOC in the UGmax field as compared to the control (Table 4), indicates that the biofertilizer UGmax plays a significant role in the activation of the transformation processes, which results in the creation of macromolecular compounds.

The CHAs/CFAs ratio is an important parameter of organic matter quality and its higher values correspond to a higher humification rate and a higher degree of the humified polymerization fractions (Valarini et al. 2003) It is generally accepted that humus with a higher $\mathrm{CHAs} / \mathrm{CFAs}$ ratio is characteristic for more fertile soils. Prior to the experiment, the mean values of the CHAs/CFAs ratio was significantly higher in the control plot compared to the plot where the UGmax was to be applied (Fig. 3). After 3 years of the study, the CHAs/CFAs ratio was significantly higher in the UGmax field than in control plot, and therefore, attention should be paid to the significant increase of this ratio between the plot with UGmax in 2005 and 2008. This is the consequence of a significant increase in the content of CFAs simultaneously with only slight changes in the concentration of CHAs. The application of UGmax resulted in an increase in the CHAs/CFAs ratio, which is very beneficial because of the organic matter quality and its stability (Orlov 1986; Gonet 1989; Dębska 2004; Yang et al. 2004). In summary, the increase of both total organic carbon and humic acids and humins along with the simultaneous decrease in the content and the contribution of dissolved organic matter can suggest that an increase in the activity of soil microorganisms accelerated the process of the degradation of dissolved organic carbon. According to

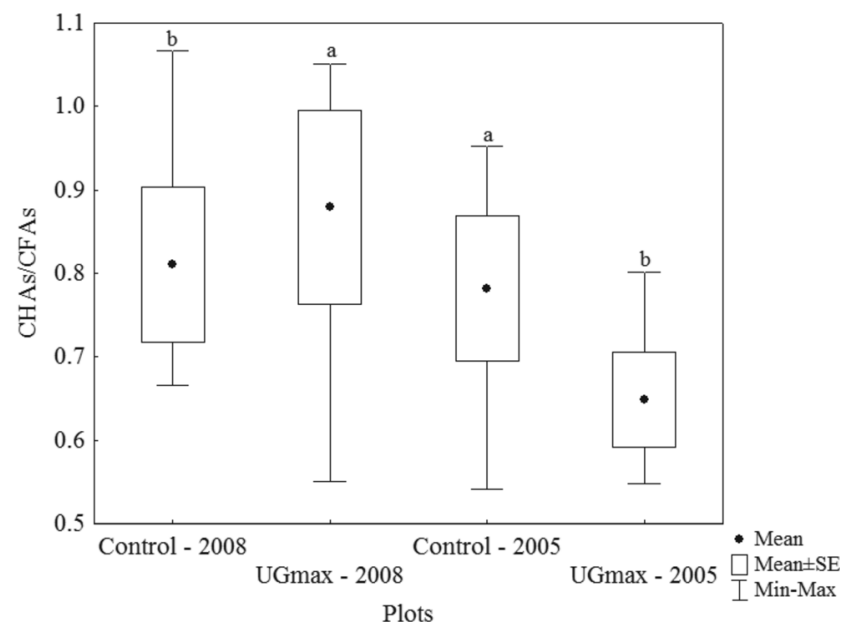

Fig. 3 CHAs/CFAs ratio; mean and standard error is given on each bar; values followed by the same lowercase letter in the same year are not significantly different at $p \leq 0.05$ 
Kalbitz et al. (2003) and Kiikkilä et al. (2014), microorganisms may use simple compounds, such as carbohydrates and amino acids during the degradation of dissolved organic matter and transform them into more composite molecules that have a higher aromaticity.

\section{Conclusions}

The application of UGmax on arable soil resulted in significant changes in the quantity and quality of soil organic matter. Organic matter in the soil treated with UGmax had a higher TOC content, a higher content and contribution of CHAs and $\mathrm{C}$ humin in TOC, higher CHAs/CFAs ratio and a lower content of DOC as compared to the control. The use of a biofertilizer that increases the formation of permanent humus compounds provides evidence of an increase in the soil organic matter stability. Consequently, the contribution of the organic matter fractions that are more resistant to decomposition is crucial for increasing soil carbon sequestration. Therefore, beneficial soil microbes should be further studied and exploited for the development of sustainable agriculture as an ecological alternative for soil fertility management. Despite the fact that some research activity has been done to document the effects (or noneffects) of many bio-fertilizers on crop production or on soil processes, little is known about the mechanisms that drive bio-fertilizers and their molecular determinants. Accordingly, further investigation should be performed to recognize and improve the survival, establishment, and performance of microorganisms when applied to soil.

Acknowledgments The authors thank the UTP University of Science and Technology in Bydgoszcz for supporting this work. Much gratitude is due to Michele Simmons for proof reading the article.

Open Access This article is distributed under the terms of the Creative Commons Attribution 4.0 International License (http:// creativecommons.org/licenses/by/4.0/), which permits unrestricted use, distribution, and reproduction in any medium, provided you give appropriate credit to the original author(s) and the source, provide a link to the Creative Commons license, and indicate if changes were made.

\section{References}

Chander K, Goyal S, Mundra MC, Kapoor KK (1997) Organic matter, microbial biomass and enzyme activity of soils under different crop rotation in the tropics. Biol Fertil Soils 24:306-310

Chen CR, Xu ZH (2008) Analysis and behavior of soluble organic nitrogen in forest soils. J Soils Sediments 8:363-378

Dębska B (2004) Properties of humic substances of soil fertilized with slurry, Ph.D. diss., UTA, Bydgoszcz (in Polish)

Dębska B, Drag M, Tobiasova E (2012) Effect of post-harvest residue of maize, rapeseed, and sunflower on humic acids properties in various soils. Pol J Environ Stud 21(3):603-613

Dinesh R, Srinivasan V, Hamza S, Manjusha A (2010) Short-term incorporation of organic manures and biofertilizers influences biochemical and microbial characteristics of soils under an annual crop [Turmeric (Curcuma longa L.)]. Bioresour Technol 101:46974702

COM Directive (2006) 232 (2006). EC (European Commission) Thematic Strategy for Soil protection. COM (2006) 232 final, 22.9.2006. EC, Brussels, EU, pp 29

Fatunbi AO, Ncube L (2009) Activities of Effective Microorganisms (EM) on the nutrient dynamics of different organic materials applied to soil. Am Eurasian J Agron 2(1):26-35

Gonet SS (1989) Properties of humic acids of soils of varied fertilisation. Dissertation, UTA Bydgoszcz (in Polish)

Gonet SS, Dębska B (1999) Properties of humic acids produced during decomposition of plant residues in soil. Rost Vyroba 45(10):455460

Gonet SS, Dębska B (2006) Dissolved organic carbon and dissolved nitrogen in soil under different fertilization treatments. Plant Soil Environ 52(2):55-63

Gonet SS, Dębska B, Pakula J (2002) The content of dissolved organic carbon in soils and organic fertilisers (in Polish), 1st edn. PTSH Wrocław

Guo J, Zhang M, Zhang L, Deng A, Bian X, Zhu J, Zhang W (2011) Responses of dissolved organic carbon and dissolved nitrogen in surface water and soil to $\mathrm{CO}_{2}$ enrichment in paddy field. Agric Ecosyst Environ 140(1-2):273-279

Haynes RJ (2005) Labile organic matter fractions as central components of the quality of agricultural soils: an overview. Adv Agron 85:221-268

IUSS Working Group WRB (2007) World References Base for Soil Resources 2006. Update 2007, World Soil Resources Reports, 103, FAO, Rome, pp 115

Jakubus M, Gajewski P, Kaczmarek Z, Mocek A (2013) Impact of addition of organic additives and EM-A preparation on physical, chemical and structural state of the arable-humus soil horizon. J Res Appl Agric Engin 58(3):220-225

Kaczmarek Z, Jakubus M, Grzelak M, Mrugalska L (2008) Impact of the addition of various doses of effective microorganisms to arablehumus horizons of mineral soils on their physical and water properties. J Res Appl Agric Engin 53(3):118-121

Kalbitz K, Schwesig D, Schmerwitz J, Kaiser K, Haumaier L, Glaser B, Ellerbrock R, Leinweber P (2003) Changes in properties of soilderived dissolved organic matter induced by biodegradation. Soil Biol Biochem 35:1129-1142

Khaliq A, Kaleem Abbasi M, Hussain T (2006) Effects of integrated use of organic and inorganic nutrient sources with effective microorganisms (EM) on seed cotton yield in Pakistan. Bioresour Technol 97: 967-972

Kiikkilä O, Kanerva S, Kitunen V, Smolander A (2014) Soil microbial activity in relation to dissolved organic matter properties under different tree species. Plant Soil 377:169-177

Krasowicz S, Oleszek W, Horabik J, Debicki R, Jankowiak J, Styczyński T, Jadczyszyn J (2011) Rational management of the soil environment in Poland. Pol J Agron 7:43-58

Kucuker MA, Guney M, Oral HV, Copty NK, Onay TT (2015) Impact of deforestation on soil carbon stock and its spatial distribution in the Western Black Sea Region of Turkey. J Environ Manag 147:227-235

Lal R (2011) Sequestering carbon in soils of agro-ecosystems. Food Policy 36:533-539

Li W, Pan KW, Wu N, Wang JC, Wang YJ, Zhang L (2014) Effect of litter type on soil microbial parameters and dissolved organic carbon in a laboratory microcosm. Plant Soil Environ 60(4):170-176

Liu E, Yan C, Mei X, He W, Bing SH, Ding L, Liu Q, Liu S, Fan T (2010) Long-term effects of chemical fertilizers, straw, and manure on soil chemical and biological properties in northwest China. Geoderma 158:173-180

Marschner B, Kalbitz K (2003) Controls of bioavailability and biodegradability of dissolved organic matter in soils. Geoderma 113:211-235 
Mayer J, Scheid S, Widmer F, Fließbach A, Oberholzer HR (2010) How effective are 'Effective microorganisms ${ }^{\circledR}(\mathrm{EM})$ '? Results from a field study in temperate climate. Appl Soil Ecol 46:230-239

Melero S, Ruiz Porras JC, Herencia JF, Madejón E (2006) Chemical and biochemical properties in a silty loam soil under conventional and organic management. Soil Till Res 90:162-170

Nisha R, Kaushik A, Kaushik CP (2007) Effect of indigenous cyanobacterial application on structural stability and productivity of an organically poor semi-arid soil. Geoderma 138:49-56

Orlov DS (1986) Humus acids of soils, 1st edn. A.A. Balkema, Rotterdam

Pardo T, Almendros G, Zancada MC, López-Fando C (2010) Biofertilization of degraded Southern African soils with cyanobacteria affects organic matter content and quality. Arid Land Res Manage 24(4):328-343

Piotrowska A, Długosz J, Zamorski R, Bogdanowicz P (2012) Changes in some biological and chemical properties of an arable soil treated with the microbial biofertilizer UGmax. Pol J Environ Stud 21(2): 455-463

Schenck zu Schweinsberg-Mickan M, Müller T (2009) Impact of effective microorganisms and other biofertilizers on soil microbial characteristics, organic matter decomposition, and plant growth. J Plant Nutr Soil Sci 172:704-712

Smith P (2004) Carbon sequestration in croplands: the potential in Europe and the global context. Eur J Agron 20:29-236
Tejada M, Benitez C, Gomez I, Parrado J (2011) Use of biostimulants on soil restoration: effects on soil biochemical properties and microbial community. Appl Soil Ecol 49:11-17

Valarini PJ, Díaz MC, Gascó JM, Guerrero F, Tokeshi H (2003) Assessment of soil properties by organic matter and EMMicroorganisms incorporation. R Bras Ci Solo 27:519-525

Ventorino V, De Marco A, Pepe O, De Santo AV, Moschetti G (2011) Impact of innovative agricultural practices of carbon sequestration on soil microbial community. In: Piccolo A (ed) Carbon sequestration in agricultural soils. Springer Verlag, Berlin. doi:10.1007/9783-642-23385-2

Wilding LP (1985) Spatial variability: its documentation, accommodation, and implication to soil surveys. In: Nielsen DR, Bouma J (eds) Soil spatial variability. Pudoc, Wageningen, pp 166-194

Wu SC, Cao ZH, Li ZG, Cheung KC, Wong MH (2005) Effects of biofertilizer containing $\mathrm{N}$-fixer, $\mathrm{P}$ and $\mathrm{K}$ solublizers and AM fungi on maize growth: a greenhouse trial. Geoderma 125:155-166

Yang ZH, Singh BR, Sitaula BK (2004) Soil organic carbon fractions under different land uses in Mardi Watershed of Nepal. Commun Soil Sci Plant Anal 35:615-629

Zhao Y, Li W, Zhou Z, Wang L, Pan L, Zhao L (2005) Dynamics of microbial community structure and cellulolytic activity in agricultural soil amended with two biofertilizers. Eur J Soil Biol 41:21-29 